\title{
Effect of lactation stage on the concentration of essential and selected toxic elements in milk of Dubrovačka ruda - Croatian endangered breed
}

doi: $10.15567 /$ mljekarstvo.2016.0407

\begin{abstract}
Zvonko Antunovićc ${ }^{*}$, Ivica Marić ${ }^{2}$, Josip Novoselec ${ }^{1}, Z_{\text {denko Lončarić }}{ }^{1}$, Boro Mioč ${ }^{3}$, Meri Engler ${ }^{1}$, Darko Kerovec ${ }^{1}$, Danijela Samac ${ }^{1}$, Željka Klir ${ }^{1}$

${ }^{1}$ University of J. J. Strossmayer in Osijek, Faculty of Agriculture in Osijek, K. P. Svačića 1d, 31000 Osijek, Croatia ${ }^{2}$ Croatian Agricultural Agency, Marka Marojice 4, 20000 Dubrovnik, Croatia ${ }^{3}$ University of Zagreb, Faculty of Agriculture, Svetošimunska cesta 25, 10000 Zagreb, Croatia
\end{abstract}

Received - Prispjelo: 15.06.2016. Accepted - Prihvaćeno: 20.10.2016.

\begin{abstract}
The aim of the present study was to determine the lactation stage effect on the concentration of essential and selected toxic elements in the sheep's milk of Dubrovačka ruda. The research was conducted with 23 sheep, average age of 4 years, of $3^{\text {rd }}$ lactation, while the milk samples were taken during the early $\left(60^{\text {th }}\right.$ day $)$, middle $\left(90^{\text {th }}\right.$ day $)$ and late $\left(120^{\text {th }}\right.$ day) lactation stage. The sheep were selected according to uniformed body development, adequate health status, body condition, equable age (4 years), parity ( $3^{\text {rd }}$ lactation), stage of lactation ( \pm 7 days) and litter size (single). Sheep were reared on the extensive Mediterranean pastures, reared indoors afterwards, fed with hay ad libitum and feed mixtures in average $0.5 \mathrm{~kg} /$ day. Milk sample was collected during morning milking from each sheep. The digested samples were analyzed with continuous flow hydride generation technique using inductively coupled plasma for $\mathrm{Ca}, \mathrm{Mg}, \mathrm{K}, \mathrm{P}, \mathrm{Na}, \mathrm{Cu}, \mathrm{Fe}, \mathrm{Zn}, \mathrm{Mn}, \mathrm{Ni}, \mathrm{Mo}, \mathrm{Co}, \mathrm{Cr}, \mathrm{Cd}$ and $\mathrm{Pb}$ concentrations. Significant increase of $\mathrm{Mg}, \mathrm{Na}, \mathrm{Se}, \mathrm{Mn}, \mathrm{Mo}$ and $\mathrm{Cd}$ concentrations were found in milk as well as decrease of $\mathrm{K}$ concentration during the lactation. Although the concentration of $\mathrm{Ca}$, $\mathrm{Cu}, \mathrm{Cr}$ and $\mathrm{As}$ in milk during the lactation is increased, the differences between the lactation stages were not observed. Concentrations of $\mathrm{P}, \mathrm{Fe}, \mathrm{Ni}, \mathrm{Pb}$ and $\mathrm{Hg}$ in milk of Dubrovačka ruda did not differ during the lactation. The low concentrations of $\mathrm{Cr}, \mathrm{Cd}, \mathrm{Pb}, \mathrm{As}, \mathrm{Hg}$ in milk indicate the safety for consumers and preserved environment of Dubrovnik-Neretva County.
\end{abstract}

Key words: sheep, milk, essential elements, toxic elements, lactation stage

\section{Introduction}

The sheep's milk is an important source of nutritive substances in the diet of growing up animals and man (Ivanova, 2011). Twenty mineral elements are essential for human population $(\mathrm{Na}, \mathrm{K}$, $\mathrm{Cl}, \mathrm{Ca}, \mathrm{Mn}$, Se, I, Cr, Co, Mo, F, Ar, Ni, Si, Bo) (Cashman, 2006), and they are categorized in 2 groups, macroelements and microelements. All essential elements have to be given in milk because of the lambs' development (Bates and Prentice, 1996). Their concentration in milk depends on various factors from environmental condition during pasture, feeding, breeding, stage and number of lactation, climate to post-milking handling, transportation and processing (Vahčić et al., 2010; Zamberlin et al., 2012). Suttle (2010) pointed out that milk is rich source of $\mathrm{Ca}, \mathrm{P}, \mathrm{K}, \mathrm{Cl}$ and $\mathrm{Zn}$, but poor source of $\mathrm{Mg}, \mathrm{Fe}, \mathrm{Cu}$ and $\mathrm{Mn}$. Concentrations of selected toxic elements, primarily heavy metals in environment generally used as an early indicator of contamination phenomena both in programs of soil quality control and in air quality monitoring (Caggiano et al., 2005; Gonzàlez-Montaña et

*Corresponding author/Dopisni autor: E-mail: zantunovic@pfos.hr 
al., 2012). Nutritional habit of sheep to graze plants and grass may be considered as environmental bio-indicator and their milk as good matrix to monitor the pollution status (Miedico et al., 2015). The heavy metals are responsible for many pernicious effects on human health such as saturnism (lead contamination), immunodepression and skin diseases (zinc and copper contamination), cancer (cadmium), hyperkeratosis (arsenic), neurological disorders (manganese) or blood disorders (iron) (Konuspayera et al., 2009).

According to the data obtained by Croatian Agricultural Agency (2015) in the Republic of Croatia only 774 heads of Dubrovačka ruda (611 ewes, 128 yearlings and 38 rams) are reared which is why it is the only critically endangered breed of sheep. Dubrovačka ruda is accounted in combined breeds of triple direction of production (wool, meat and milk), although last years emphasized in milk and meat production. Exterior and metabolic profile of blood as well as chemical composition of milk from Dubrovačka ruda are already investigated (Mioč et al., 2004; Antunović et al., 201 la and b; Antunović et al., 2015). However, in available literature there is no research about concentration of essential and selected toxic elements in milk of Dubrovačka ruda nor in milk of other Croatian native breeds. Sheep in the Republic of Croatia are mostly reared for meat production, but recently the interest for milk production is favored, especially for good quality cheese production (Antunović et al., 2012). As one of the best reasons for farming of Dubrovačka ruda is also production of good quality traditional food and other products (Marić et al., 2014).

Thus, the aim of the present study is to determine the concentration of essential and toxic elements in the milk of Dubrovačka ruda according to different stages of lactation and to research whether is the milk from sheep reared on Mediterranean pastures in Dubrovnik-Neretva County of preserved quality.

\section{Material and methods}

\section{Experimental design}

The research was conducted on family farm having a long tradition of sheep farming in Dubrovnik-Neretva County. From the herd of 100 grown up Dubrovačka ruda, 23 dairy sheep were selected and were monitored during the lactation. The sheep were grouped according to uniformed body development, adequate health status, body condition, equable age (4 years), parity ( $3^{\text {rd }}$ lactation), stage of lactation ( \pm 7 days) as well as equal litter size (single). Sheep were reared on the extensive Mediterranean pastures from early morning until 10:00 a.m. when they are returned in the barn, fed with hay ad libitum and $0.5 \mathrm{~kg}$ of cereals' mixture per day (oat + barley + corn). Water and salt were continuously available and offered to animals. Milking was conducted manually. Lactation was divided on early (60 days), middle (90 day) and late (120 days) stage. After lambing, lambs were kept together with their mothers and reared on the pastures until age of 90 days.

\section{Soil and plants analysis}

Soil layer on depth $0-30 \mathrm{~cm}$ at each location were sampled as composite samples (20-25 subsamples). Soil samples were prepared for chemical analyses according to procedure for pretreatment of samples for physico-chemical analyses (ISO, 1994). Soil samples were ground by heavy metal free grinder (Retsch RM 200, Germany) and sieved through the sieves of $2 \mathrm{~mm}$. The concentrations of mineral elements in soil samples were extracted by aqua regia (ISO, 1995) and this fraction was considered as soil total content. The soil samples were digested at $210{ }^{\circ} \mathrm{C}$ for $60 \mathrm{~min}$ in microwave oven (CEM Mars 6 , USA).

The concentrations of mineral elements in extracts were determined by ICP-OES (PerkinElmer Optima 2100 DV, USA). Each batch of soil samples run on the inductively coupled plasma was analysed with an internal pooled plasma control and with the reference material prepared in the same way as were the soil samples extracted by aqua regia. All samples were analysed in duplicate, and all soil samples from the same year were analysed within the same analytic run. The instrumental detection and quantification limits for the determination of essential minerals and selected toxic elements in soil, sheep's milk and feed $(\mathrm{mg} / \mathrm{kg})$ are presented in Table 1.

All plant samples (cereals' mixture, hay and green forage from pastures) were dried and ground into a fine powder using a heavy metal free ultracentrifugal mill (Retsch RM 200, Germany) or knife 
mill (GM 200, Germany). All plant samples were digested with $10 \mathrm{~mL}$ of a 5:1 mixture of $\mathrm{HNO}_{3}$ and $\mathrm{H}_{2} \mathrm{O}_{2}$ at $180^{\circ} \mathrm{C}$ for $60 \mathrm{~min}$ in microwave oven (CEM Mars 6, USA). The concentrations of mineral elements in solutions of digested plant samples were determined by inductively coupled plasma (ICP, PerkinElmer Optima 2100 DV, USA). Each batch of plant samples run on the ICP was analyzed with an internal pooled plasma control and with the reference material prepared in the same way as were the other plant samples. All samples were analyzed in duplicate. Concentrations of mineral elements and selected toxic element in soil and feed of ewes $(\mathrm{mg} / \mathrm{kg})$ are presented in Table 2.

\section{Milk digestion and preparation for analyses}

Before collecting of raw milk sampling bottles were soaked in $20 \% \mathrm{HNO}_{3}$ for 24 hours and washed with deionized water in order to avoid possible contamination. A milk sample of $100 \mathrm{~mL}$ was collected during morning milking from each sheep, homogenized, stored in fridge box at the $4{ }^{\circ} \mathrm{C}$, and transferred in the deep freeze $\left(-80^{\circ} \mathrm{C}\right)$ afterwards, until microwave digestion was carried out.
The digestion of milk samples was carried out according to method described by Belete et al. (2014). A $3.0 \mathrm{~mL}$ of each liquid milk sample was transferred into $60 \mathrm{~mL}$ Teflon digestion vessel and then optimized volumes of $6 \mathrm{~mL} 70 \%$ nitric acid and $1 \mathrm{~mL}$ of $30 \%$ hydrogen peroxide were added and the mixture was shaken carefully and kept for $10 \mathrm{~min}$ before closing the vessel. The samples were subjected to closed microwave digestion at the optimized microwave digestion program in the sequence as follows: $50 \mathrm{~W}, 165{ }^{\circ} \mathrm{C}(10 \mathrm{~min}) ; 80 \mathrm{~W}, 190{ }^{\circ} \mathrm{C}$ (20 min); and $0 \mathrm{~W}, 50{ }^{\circ} \mathrm{C}(10 \mathrm{~min})$ carried out on Mars 6 (CEM, Matthews, NC, USA) microwave system. After heating, the sample was cooled to room temperature and the digestion vessels were opened carefully in a digester. The digest was diluted to $25 \mathrm{~mL}$ with deionized water and used for analysis afterwards.

The digested samples was analyzed with continuous flow hydride generation technique using ICP (Optima 21000 DV, Perkin Elmer, Massachussets, $\mathrm{SAD}$ ) for $\mathrm{Ca}, \mathrm{Mg}, \mathrm{K}, \mathrm{P}, \mathrm{Na}, \mathrm{Cu}, \mathrm{Fe}, \mathrm{Zn}, \mathrm{Mn}$, $\mathrm{Ni}, \mathrm{Mo}, \mathrm{Co}, \mathrm{Cr}, \mathrm{Cd}$ and $\mathrm{Pb}$ concentrations. The digested milk samples provided for $\mathrm{Se}$, As and $\mathrm{Hg}$

Table 1. Instrumental detection and quantification limits for the determination of essential minerals and selected toxic elements in soil, sheep's milk and feed (mg/kg)

\begin{tabular}{ccccc}
\hline \multirow{2}{*}{$\begin{array}{c}\text { Minerals/ } \\
\text { Heavy metals }\end{array}$} & Milk & Soil and feed & Milk & Soil and feed \\
\cline { 2 - 5 } $\mathrm{Ca}$ & 0.06606 & 0.6606 & 0.202 & 2.02 \\
\hline $\mathrm{Mg}$ & 0.01098 & 0.1098 & 0.0366 & 0.366 \\
\hline $\mathrm{K}$ & 0.54 & 5.40 & 1.81 & 18.1 \\
\hline $\mathrm{Cu}$ & 0.005422 & 0.054219 & 0.018073 & 0.18073 \\
\hline $\mathrm{Fe}$ & 0.005433 & 0.05433 & 0.01811 & 0.1811 \\
\hline $\mathrm{Zn}$ & 0.000934 & 0.009339 & 0.003113 & 0.03113 \\
\hline $\mathrm{Mn}$ & 0.000024 & 0.00024 & 0.00008 & 0.0008 \\
\hline $\mathrm{Ni}$ & 0.0027 & 0.027 & 0.009045 & 0.09045 \\
\hline $\mathrm{Mo}$ & 0.00318 & 0.0318 & 0.01069 & 0.1069 \\
\hline $\mathrm{Co}$ & 0.00115 & 0.0115 & 0.003836 & 0.03836 \\
\hline $\mathrm{Cr}$ & 0.000941 & 0.009405 & 0.003135 & 0.031350 \\
\hline $\mathrm{Cd}$ & 0.00063 & 0.0063 & 0.00212 & 0.0212 \\
\hline $\mathrm{Pb}$ & 0.01001 & 0.1001 & 0.0333 & 0.0212 \\
\hline $\mathrm{As}$ & 0.00007735 & 0.002466 & 0.0333 & 0.00822 \\
\hline $\mathrm{Hg}$ & 0.000288 & 0.000663 & 0.00221 & 0.00221 \\
\hline
\end{tabular}

IDL - instrumental detection limit; IQL - instrumental quantification limit 
determination were subjected to pre-reduction step before the analysiswere done according to Bosnak and Davidowski (2004). For the pre-reduction of As, $20 \mathrm{~mL}$ of sample was placed in a $50 \mathrm{~mL}$ polypropylene autosampler tube. To that, $2 \mathrm{~mL}$ of a $5 \%$ solution of KI and ascorbic acid was added. Six mL of concentrated $\mathrm{HCl}$ was also added, and the mixture was allowed to stand for at least 20 minutes. The tube was brought to the $50 \mathrm{~mL}$ mark with deionized water and the sample was ready to run. For the pre-reduction of Se and $\mathrm{Hg}, 20 \mathrm{~mL}$ of sample was placed in a cleaned $125 \mathrm{~mL}$ beaker and $20 \mathrm{~mL}$ of concentrated $\mathrm{HCl}$ was slowly added. The solution was then transferred to a $50 \mathrm{~mL}$ polypropylene autosampler tube which was diluted to the $50 \mathrm{~mL}$ mark with deionized water. The samples were ready to run with inductively coupled plasma (Optima 21000 DV, Perkin Elmer, Massachussets, USA).

\section{Statistical analysis}

A total number of 69 observations were collected for mineral composition of milk during early, middle and late lactation stage. Data were analyzed with the statistical software SAS $9.3^{\circledR}$. The results are presented as arithmetic mean with standard deviation and standard error of mean estimated with MEANS procedure, while the Pearson's correlation between essential or toxic elements was estimated with CORR procedure. Data were analyzed with GLM procedure using lactation stage as fixed effect. Means were compared using the LSD test and differences between lactation stage effect declared significant at $\mathrm{p}<0.05$ level.

Table 2. Concentrations of mineral elements and selected toxic element in soil and feed of sheep $(\mathrm{mg} / \mathrm{kg})$

\begin{tabular}{ccccc}
\hline \multirow{2}{*}{ Minerals/Heavy metals } & Soil & \multicolumn{3}{c}{ Feedstuffs } \\
\cline { 2 - 5 } & & Cereals' mixture & Hay & Green forage \\
\hline $\mathrm{Ca}$ & 35915.61 & 611.40 & 10165.10 & 10771.91 \\
\hline $\mathrm{Mg}$ & 14439.33 & 1314.56 & 2372.11 & 3720.73 \\
\hline $\mathrm{K}$ & 4649.23 & 4436.40 & 7803.91 & 16406.61 \\
\hline $\mathrm{P}$ & 625.89 & 3322.00 & 1277.00 & 2508.77 \\
\hline $\mathrm{Na}$ & 337.65 & 147.22 & 1930.61 & 524.22 \\
\hline $\mathrm{Cu}$ & 131.20 & 3.13 & 6.09 & 9.45 \\
\hline $\mathrm{Fe}$ & 16852.29 & 386.80 & 111.60 & 217.24 \\
\hline $\mathrm{Zn}$ & 52.35 & 28.74 & 24.82 & 30.30 \\
\hline $\mathrm{Se}$ & 0.38 & 0.019 & 0.492 & 0.11 \\
\hline $\mathrm{Mn}$ & 414.45 & 35.46 & 18.87 & 52.81 \\
\hline $\mathrm{Ni}$ & 25.42 & 0.764 & 0.496 & 0.55 \\
\hline $\mathrm{Mo}$ & - & 0.333 & 2.263 & 2.46 \\
\hline $\mathrm{Co}$ & 7.61 & 0.129 & 0.099 & 0.13 \\
\hline $\mathrm{Cr}$ & 33.63 & 0.538 & 0.306 & 0.53 \\
\hline $\mathrm{Cd}$ & 0.58 & $<\mathrm{LD}$ & 0.139 & 0.06 \\
\hline $\mathrm{Pb}$ & 28.43 & 0.447 & $<0.333$ & 0.47 \\
\hline $\mathrm{As}$ & 13.05 & 0.132 & 0.036 & 0.14 \\
\hline $\mathrm{Hg}$ & 0.08 & 0.002 & 0.008 & 0.01 \\
\hline $\mathrm{Hit}$ & & &
\end{tabular}

LD - detection limit 
Table 3. Descriptive statistics for concentrations of essential minerals and selected toxic elements in sheep's milk

\begin{tabular}{ccccc}
\hline Element, $\mathrm{mg} / \mathrm{kg}$ & Mean $\pm \mathrm{SD}$ & SEM & MIN. & MAX. \\
\hline $\mathrm{Ca}$ & $2067.97 \pm 262.20$ & 31.80 & 1301.04 & 2834.36 \\
\hline $\mathrm{Mg}$ & $185.00 \pm 23.05$ & 2.80 & 125.08 & 234.15 \\
\hline $\mathrm{K}$ & $1334.99 \pm 158.19$ & 19.18 & 978.27 & 1763.88 \\
\hline $\mathrm{P}$ & $1276.99 \pm 152.61$ & 18.51 & 919.42 & 1714.01 \\
\hline $\mathrm{Na}$ & $411.73 \pm 173.71$ & 21.07 & 246.09 & 1264.73 \\
\hline $\mathrm{Cu}$ & $0.062 \pm 0.03$ & 0.003 & 0.02 & 0.15 \\
\hline $\mathrm{Fe}$ & $0.81 \pm 0.80$ & 0.099 & 0.19 & 5.24 \\
\hline $\mathrm{Zn}$ & $4.36 \pm 1.42$ & 0.17 & 2.14 & 11.01 \\
\hline $\mathrm{Se}$ & $0.023 \pm 0.004$ & 0.0005 & 0.017 & 0.034 \\
\hline $\mathrm{Mn}$ & $0.047 \pm 0.031$ & 0.004 & 0.006 & 0.198 \\
\hline $\mathrm{Ni}$ & $0.073 \pm 0.224$ & 0.027 & 0.003 & 0.849 \\
\hline $\mathrm{Mo}$ & $0.059 \pm 0.055$ & 0.007 & 0.024 & 0.005 \\
\hline $\mathrm{Co}$ & $0.003 \pm 0.002$ & 0.0002 & 0.0012 & 0.444 \\
\hline $\mathrm{Cr}$ & $0.036 \pm 0.052$ & 0.006 & 0.019 & 0.002 \\
\hline $\mathrm{Cd}$ & $0.002 \pm 0.001$ & 0.0001 & 0.0006 & 0.035 \\
\hline $\mathrm{Pb}$ & $0.0185 \pm 0.017$ & 0.002 & 0.0100 & 0.0009 \\
\hline $\mathrm{As}$ & $0.0003 \pm 0.0001$ & 0.00002 & 0.00008 & 0.0009 \\
\hline $\mathrm{Hg}$ & $0.0001 \pm 0.0003$ & 0.0004 & 0.00029 &
\end{tabular}

$\mathrm{Sd}$ - standard deviation, SEM - standard error of mean, min - minimum value, max - maximum value

Table 4. Concentrations of essential minerals in sheep's milk during different stages of lactation

\begin{tabular}{cccccc}
\hline \multirow{2}{*}{$\begin{array}{c}\text { Element } \\
\mathrm{mg} / \mathrm{kg}\end{array}$} & Early & Middle & Late & SEM & p-value \\
\cline { 2 - 4 } $\mathrm{Ca}$ & $1971.68^{\mathrm{a}} \pm 276.86$ & $2108.17^{\mathrm{a}} \pm 196.18$ & $2115.16^{\mathrm{a}} \pm 311.97$ & 31.80 & 0.274 \\
\hline $\mathrm{Mg}$ & $163.33^{\mathrm{b}} \pm 16.67$ & $195.12^{\mathrm{a}} \pm 16.62$ & $194.02^{\mathrm{a}} \pm 21.48$ & 2.79 & $<0.001$ \\
\hline $\mathrm{K}$ & $1441.86^{\mathrm{a}} \pm 154.57$ & $1305.68^{\mathrm{b}} \pm 125.40$ & $1260.05^{\mathrm{b}} \pm 149.87$ & 19.18 & $<0.001$ \\
\hline $\mathrm{P}$ & $1277.28^{\mathrm{a}} \pm 174.20$ & $1244.20^{\mathrm{a}} \pm 141.47$ & $1324.99^{\mathrm{a}} \pm 137.28$ & 18.51 & 0.295 \\
\hline $\mathrm{Na}$ & $322.94^{\mathrm{b}} \pm 56.53$ & $401.19^{\mathrm{b}} \pm 129.32$ & $525.42^{\mathrm{a}} \pm 246.31$ & 21.07 & $<0.001$ \\
\hline $\mathrm{Cu}$ & $0.05^{\mathrm{a}} \pm 0.03$ & $0.06^{\mathrm{a}} \pm 0.02$ & $0.07^{\mathrm{a}} \pm 0.02$ & 0.003 & 0.076 \\
\hline $\mathrm{Fe}$ & $0.72^{\mathrm{a}} \pm 0.47$ & $0.97^{\mathrm{a}} \pm 1.11$ & $0.66^{\mathrm{a}} \pm 0.57$ & 0.10 & 0.679 \\
\hline $\mathrm{Zn}$ & $5.18^{\mathrm{a}} \pm 1.94$ & $3.56^{\mathrm{b}} \pm 0.68$ & $4.64^{\mathrm{a}} \pm 0.89$ & 0.17 & $<0.001$ \\
\hline $\mathrm{Se}$ & $0.020^{\mathrm{c}} \pm 0.004$ & $0.026^{\mathrm{a}} \pm 0.003$ & $0.023^{\mathrm{b}} \pm 0.003$ & 0.0005 & $<0.001$ \\
\hline $\mathrm{Mn}$ & $0.023^{\mathrm{b}} \pm 0.012$ & $0.046^{\mathrm{a}} \pm 0.014$ & $0.08^{\mathrm{c}} \pm 0.04$ & 0.003 & $<0.001$ \\
\hline $\mathrm{Ni}$ & $0.058^{\mathrm{a}} \pm 0.088$ & $0.032^{\mathrm{a}} \pm 0.015$ & $0.150^{\mathrm{a}} \pm 0.412$ & 0.027 & 0.087 \\
\hline $\mathrm{Mo}$ & $0.055^{\mathrm{a}} \pm 0.025$ & $0.046^{\mathrm{b}} \pm 0.012$ & $0.081^{\mathrm{a}} \pm 0.100$ & 0.007 & 0.038 \\
\hline $\mathrm{Co}$ & $0.003^{\mathrm{b}} \pm 0.002$ & $0.002^{\mathrm{c}} \pm 0.002$ & $0.004^{\mathrm{a}} \pm 0.0003$ & 0.0002 & $<0.001$ \\
\hline
\end{tabular}

a,b Means within a row with different superscripts differ $(\mathrm{p}<0.05)$; ${ }^{\mathrm{a}}$ Means within a row with the same superscripts - not significant; sd - standard deviation; SEM - standard error of mean 


\section{Results and discussion}

The average values of elements in sheep's milk as well as other statistical measurements (standard deviation, standard error of mean, as well as minimal and maximal values) were determined (Table 3 ). Analyzing the Table 3 it is evident that concentrations of most of the essential elements and selected toxic elements ( $\mathrm{Cr}, \mathrm{Co}, \mathrm{Mo}, \mathrm{Ni}$ and $\mathrm{Hg}$ ) in milk significantly differed according to determined high standard deviation.

It is evident that in milk of Dubrovačka ruda was found significant increase concentration of $\mathrm{Mg}$, $\mathrm{Na}, \mathrm{Se}, \mathrm{Mn}$ and Mo as well as decrease of K during the lactation (Table 4). Although the concentrations of $\mathrm{Ca}$ and $\mathrm{Cu}$ during the lactation also increased, the differences between the stages of lactation were not significant. The concentrations of $\mathrm{P}, \mathrm{Fe}$ and $\mathrm{Ni}$ did not significantly differ during the lactation. Also, significant decrease of $\mathrm{Zn}$ and Co concentrations in milk during the middle lactation, as well as significant increase in late lactation compared to early lactation.

The concentration of Cd significantly increased during the lactation in milk of Dubrovačka ruda (Table 5). Also, lower increase of $\mathrm{Cr}$ and As concentrations was found during the lactation, as well as decrease of $\mathrm{Pb}$ and $\mathrm{Hg}$, but the differences were not significant.

Numerous significant correlations were determined, mostly strong and positive, among essential minerals and toxic elements in milk of Dubrovačka ruda (Table 6). In all stages of lactation, strong positive correlations were found between $\mathrm{Mg}: \mathrm{P}$ and $\mathrm{Ca}: \mathrm{P}$, as well as negative correlation between Fe:Mn and strong negative correlation between $\mathrm{K}: \mathrm{Na}$ in milk of Dubrovačka ruda.
Concentrations of most of the microelements and toxic elements ( $\mathrm{Cr}, \mathrm{Co}, \mathrm{Mo}, \mathrm{Ni}$ and $\mathrm{Hg}$ ) in milk significantly differed according to determined high standard deviation, that could be related to low concentrations and low level of instrumental detection limit (Table 1 and 2).

Compared to present study, Coni et al. (1996) in sheep's milk in Italy found increased concentrations of $\mathrm{Cd}, \mathrm{Co}, \mathrm{Cu}, \mathrm{Fe}, \mathrm{Mg}, \mathrm{Mn}, \mathrm{Pb}$ and $\mathrm{Zn}$, as well as lower concentration of Cr. Al-Wabel (2008) found in sheep's milk in Saudi Arabia lower concentration of Zn (3.09 mg/kg), Ca (822.50 mg/kg), $\mathrm{Na}(95,40 \mathrm{mg} / \mathrm{kg})$ and $\mathrm{K}(127.41 \mathrm{mg} / \mathrm{kg})$ and increased concentration of $\mathrm{Mn}(1.144 \mathrm{mg} / \mathrm{kg}), \mathrm{Cu}$ $(0.62 \mathrm{mg} / \mathrm{kg})$ and $\mathrm{Fe}(5.01 \mathrm{mg} / \mathrm{kg})$. Khan et al. (2006) found in sheep's milk reared on pastures in Pakistan lower concentrations of the most of minerals ( $\mathrm{Ca}, \mathrm{Mg}, \mathrm{Na}, \mathrm{K}, \mathrm{Fe}, \mathrm{Se}, \mathrm{Zn})$ as well as higher concentration of $\mathrm{Cu}$ (03.243), Mn (0.88) and Co $(0.088 \mathrm{mg} / \mathrm{L})$. In milk of Bulgarian breeds of sheep (Srednostaroplaninska and Tetevenska sheep) Gerchev and Mihaylova (2012) found similar concentrations of Ca (223 and $208 \mathrm{mg} / 100 \mathrm{~g}$ ), $\mathrm{K}(131$ and $110 \mathrm{mg} / 100 \mathrm{~g}$ ) and $\mathrm{Mn}$ (0.03 and $0.02 \mathrm{mg} / 100 \mathrm{~g})$ as well as higher concentration of $\mathrm{Na}$ (49 and $50 \mathrm{mg} / 100 \mathrm{~g}$ ), P (145 and $145 \mathrm{mg} / 100 \mathrm{~g}$ ) and $\mathrm{Fe}(0.181$ and $0.12 \mathrm{mg} / 100 \mathrm{~g})$, and significantly higher $\mathrm{Mg}$ (1807 and $1657 \mathrm{mg} / 100 \mathrm{~g}$ ), $\mathrm{Cu}(0.043$ and $0.040 \mathrm{mg} / 100 \mathrm{~g})$ and $\mathrm{Zn}(0.71$ and $0.62 \mathrm{mg} / 100 \mathrm{~g})$. Similar concentrations of $\mathrm{Ca}, \mathrm{Mg}, \mathrm{Zn}, \mathrm{Mn}$ and higher of $\mathrm{P}, \mathrm{K}$ and $\mathrm{Cu}$ in sheep's milk was found in the research by Suttle (2010). Miedico et al. (2015) found in sheep's milk in Italy significantly higher concentrations of $\mathrm{Cu}, \mathrm{Fe}, \mathrm{Mn}$ and $\mathrm{As}(130 ; 1160$; 89.6 and $5.13 \mathrm{ng} / \mathrm{g})$, higher $\mathrm{Zn}(5170 \mathrm{ng} / \mathrm{g})$, and similar concentrations of Se, Mo, Co (29.9; 40.7 and

Table 5. Concentrations of selected toxic elements in sheep's milk during different stages of lactation

\begin{tabular}{cccccc}
\hline \multirow{2}{*}{$\begin{array}{c}\text { Element } \\
\mathrm{mg} / \mathrm{kg}\end{array}$} & Early & Middle & Ltage of lactation $($ Mean \pm sd) & SEM & p-value \\
\cline { 2 - 4 } & $0.033^{\mathrm{a}} \pm 0.022$ & $0.027^{\mathrm{a}} \pm 0.003$ & $0.052^{\mathrm{a}} \pm 0.095$ & 0.006 & 0.119 \\
\hline $\mathrm{Cr}$ & $0.0011^{\mathrm{b}} \pm 0.001$ & $0.0017^{\mathrm{a}} \pm 0.0008$ & $0.0019^{\mathrm{a}} \pm 0.0005$ & 0.0001 & 0.003 \\
\hline $\mathrm{Cd}$ & $0.020^{\mathrm{a}} \pm 0.014$ & $0.014^{\mathrm{a}} \pm 0.017$ & $0.022^{\mathrm{a}} \pm 0.018$ & 0.002 & 0.097 \\
\hline $\mathrm{Pb}$ & $0.0003^{\mathrm{a}} \pm 0.00013$ & $0.0003^{\mathrm{a}} \pm 0.00009$ & $0.0004^{\mathrm{a}} \pm 0.0002$ & 0.00002 & 0.164 \\
\hline $\mathrm{As}$ & $0.0003^{\mathrm{a}} \pm 0.0004$ & $0.00003^{\mathrm{a}} \pm 0.0002$ & $0.0001^{\mathrm{a}} \pm 0.0003$ & 0.00004 & 0.384 \\
\hline $\mathrm{Hg}$ & &
\end{tabular}

a,b Means within a row with different superscripts differ $(\mathrm{p}<0.05)$;

${ }^{a}$ Means within a row with the same superscripts-not significant sd-standard deviation; SEM-standard error of mean. 
$3.88 \mathrm{ng} / \mathrm{g})$ as well as significantly lower concentrations of $\mathrm{Ni}, \mathrm{Cr}, \mathrm{Cd}$ and $\mathrm{Pb}(40.7 ; 2.31 ; 0.934$ and $5.13 \mathrm{ng} / \mathrm{g})$.

Polychroniadou and Vafopoulou (1985) reported about similar changes of mineral concentration in milk from sheep in Greece. However, authors found significant decrease in concentration of $\mathrm{K}$ and increase of $\mathrm{Mg}$ as well as non-significant increase of $\mathrm{Na}$ and decrease of P. Antunović et al. (2001) mentioned that concentration of minerals in milk of Merinolandschaf sheep during the lactation depended on concentration of these elements in feed. Increase of $\mathrm{Ca}$ and $\mathrm{P}$ concentration in milk of Yanakas sheep during the lactation in Nigeria (Ca: from
0.5125 to $1.78 \mathrm{~g} / \mathrm{kg}$, P: from 0.625 to $1.175 \mathrm{~g} / \mathrm{kg}$ ) found Mwaura and Akinsoyinu (2010). Sahan et al. (2005) found in milk of Awassi sheep in Turkey reared on pastures, a decrease of $\mathrm{K}$ concentration as well as slight increase of $\mathrm{Na}$ concentration during the lactation. Ivanova et al. (2009) determined in milk of Bulgarian synthetic milk sheep increase of $\mathrm{P}$ concentration during lactation. Ivanova (2011), in milk of Karakachanska sheep in Bulgaria, found similar concentration of $\mathrm{Cr}$ (from 0.06 to $0.05 \mathrm{mg} / \mathrm{kg}$ ), $\mathrm{Cu}$ (from 0.24 to $0.34 \mathrm{mg} / \mathrm{kg}$ ), Fe (from 0.8 to $1.3 \mathrm{mg} / \mathrm{kg}$ ), $\mathrm{Mn}(0.07 \mathrm{mg} / \mathrm{kg}$ ) and $\mathrm{Zn}$ (from 3.81 to $4.41 \mathrm{mg} / \mathrm{kg})$, as well as higher concentration of Se (from 25.5 to $17.5 \mathrm{mg} / \mathrm{kg}$ ).

Table 6. Significant correlations between different essential minerals and selected toxic elements in sheep's milk during different stages of lactation.

\begin{tabular}{|c|c|c|c|c|c|}
\hline \multicolumn{2}{|c|}{ Early } & \multicolumn{2}{|c|}{ Middle } & \multicolumn{2}{|c|}{ Late } \\
\hline Ratio & Correlation & Ratio & Correlation & Ratio & Correlation \\
\hline $\mathrm{Ca}: \mathrm{Zn}$ & $0.64(\mathrm{P}=0.002)$ & $\mathrm{Ca}: \mathrm{Cr}$ & $0.83(\mathrm{P}<0.001)$ & $\mathrm{Ca}: \mathrm{Na}$ & $-0.74(\mathrm{P}<0.001)$ \\
\hline Ca:P & $0.85(\mathrm{P}<0.001)$ & Ca:P & $0.82(\mathrm{P}<0.001)$ & Ca:K & $0.54(\mathrm{P}=0.016)$ \\
\hline $\mathrm{Mg}: \mathrm{Mn}$ & $0.44(\mathrm{P}=0.044)$ & $\mathrm{Ca}: \mathrm{Se}$ & $0.55(\mathrm{P}=0.002)$ & Ca:P & $0.78(\mathrm{P}<0.001)$ \\
\hline $\mathrm{Mg}: \mathrm{Zn}$ & $0.44(\mathrm{P}=0.043)$ & $\mathrm{Mg}: \mathrm{Cr}$ & $0.60(\mathrm{P}<0.001)$ & $\mathrm{Ca}: \mathrm{Se}$ & $0.58(\mathrm{P}=0.009)$ \\
\hline $\mathrm{Mg}: \mathrm{Mo}$ & $0.47(\mathrm{P}=0.030)$ & $\mathrm{Mg}: \mathrm{P}$ & $0.50(\mathrm{P}=0.007)$ & $\mathrm{Mg}: \mathrm{Cu}$ & $0.63(\mathrm{P}=0.004)$ \\
\hline $\mathrm{Mg}: \mathrm{Cr}$ & $0.44(\mathrm{P}=0.047)$ & $\mathrm{Mg}: \mathrm{Se}$ & $0.42(\mathrm{P}=0.028)$ & $\mathrm{Mg}: \mathrm{P}$ & $0.56(\mathrm{P}=0.013)$ \\
\hline Mg:P & $0.50(\mathrm{P}=0.021)$ & $\mathrm{K}: \mathrm{Na}$ & $-0.54(\mathrm{P}=0.003)$ & $\mathrm{K}: \mathrm{Na}$ & $-0.59(\mathrm{P}=0.009)$ \\
\hline $\mathrm{Na}: \mathrm{Fe}$ & $0.61(\mathrm{P}=0.003)$ & $\mathrm{Na}: \mathrm{Mo}$ & $0.39(\mathrm{P}=0.040)$ & $K: P$ & $0.58(\mathrm{P}=0.009)$ \\
\hline $\mathrm{Na}: \mathrm{Mn}$ & $0.64(\mathrm{P}=0.002)$ & $\mathrm{Cu}: \mathrm{Mo}$ & $0.39(\mathrm{P}=0.042)$ & $\mathrm{K}: \mathrm{Cd}$ & $-0.51(\mathrm{P}=0.027)$ \\
\hline $\mathrm{Na}: \mathrm{Mo}$ & $0.50(\mathrm{P}=0.021)$ & Fe:Mn & $0.37(\mathrm{P}=0.049)$ & $\mathrm{K}: \mathrm{Ni}$ & $0.50(\mathrm{P}=0.028)$ \\
\hline $\mathrm{Na}: \mathrm{P}$ & $0.44(\mathrm{P}=0.047)$ & $\mathrm{Fe}: \mathrm{Ni}$ & $0.54(\mathrm{P}=0.003)$ & $\mathrm{K}: \mathrm{Co}$ & $0.51(\mathrm{P}=0.027)$ \\
\hline Fe:Mn & $0.45(\mathrm{P}=0.038)$ & $\mathrm{Mn}: \mathrm{Hg}$ & $0.42(\mathrm{P}=0.027)$ & $\mathrm{K}: \mathrm{Cr}$ & $0.52(\mathrm{P}=0.023)$ \\
\hline $\mathrm{Mn}: \mathrm{P}$ & $0.45(\mathrm{P}=0.042)$ & $\mathrm{Zn}: \mathrm{Cd}$ & $0.39(\mathrm{P}=0.042)$ & $\mathrm{Na}: \mathrm{Zn}$ & $-0.57(\mathrm{P}=0.011)$ \\
\hline $\mathrm{Mn}: \mathrm{Se}$ & $0.76(\mathrm{P}=0.006)$ & $\mathrm{Zn}: \mathrm{P}$ & $0.45(\mathrm{P}=0.015)$ & Fe:Mn & $0.76(\mathrm{P}<0.001)$ \\
\hline $\mathrm{Zn}: \mathrm{P}$ & $0.83(\mathrm{P}<0.001)$ & Mo:Cd & $0.41(\mathrm{P}=0.029)$ & Fe:As & $0.72(\mathrm{P}<0.001)$ \\
\hline Mo: $\mathrm{Cr}$ & $0.91(\mathrm{P}<0.001)$ & Cr:P & $0.96(\mathrm{P}<0.001)$ & Mn:As & $0.73(\mathrm{P}<0.001)$ \\
\hline \multirow[t]{7}{*}{ Cr:P } & $0.50(\mathrm{P}=0.022)$ & $\mathrm{Cr}: \mathrm{Se}$ & $0.53(\mathrm{P}=0.004)$ & $\mathrm{K}: \mathrm{Se}$ & $0.49(\mathrm{P}=0.034)$ \\
\hline & & $\mathrm{Pb}: \mathrm{Cd}$ & $0.40(\mathrm{P}=0.033)$ & $\mathrm{Na}: \mathrm{Hg}$ & $0.50(\mathrm{P}=0.029)$ \\
\hline & & $\mathrm{P}: \mathrm{Se}$ & $0.59(\mathrm{P}<0.001)$ & $\mathrm{Cu}: \mathrm{Zn}$ & $-0.53(\mathrm{P}=0.019)$ \\
\hline & & & & $\mathrm{Cu}: \mathrm{Se}$ & $0.49(\mathrm{P}=0.032)$ \\
\hline & & & & $\mathrm{Zn}: \mathrm{Pb}$ & $0.50(\mathrm{P}=0.028)$ \\
\hline & & & & $\mathrm{Pb}: \mathrm{As}$ & $0.48(\mathrm{P}=0.038)$ \\
\hline & & & & $\mathrm{P}: \mathrm{Se}$ & $0.63(\mathrm{P}=0.004)$ \\
\hline
\end{tabular}


Mentioned significant increase of $\mathrm{Cd}$ and nonsignificant concentrations of $\mathrm{Cr}$ and As, as well as non-significant decrease of $\mathrm{Pb}$ and $\mathrm{Hg}$ concentrations during lactation mostly depend on feed or water intake, and possible consumption of soil (Ghidini et al., 2012). In general, sheep's milk contains very low concentrations of heavy metals (Antunovic et al., 2005). The toxic metals content of milk and dairy products is due to such factors as environmental conditions and manufacturing processes (Anastassio et al., 2006). Their concentrations in animal organisms and their milk concentrations may increase very fast, although their excretion through milk is very low (Houpert et al., 1997). It was stated that $\mathrm{Cd}$ increase was associated with protein content in cow milk (Rodriguez et al., 1999) that could be the reason of $\mathrm{Cd}$ increase during the lactation in milk of Dubrovačka ruda, because it is well known that at the end of lactation the protein content in milk is increasing. This supports the hypothesis that $\mathrm{Cd}$ is mainly associated with the protein fraction (casein fraction) obtained by enzymatic coagulation (Mata et al., 1995). In the present study significantly lower concentration of $\mathrm{Cd}$ was found compared to the permitted concentrations. Sheep excrete more $\mathrm{Pb}$ via milk relative to cows (Mehennaoui et al., 1997), which may cause higher concentrations of $\mathrm{Pb}$ in milk of Dubrovačka ruda in early and late stage of lactation. The results by Coni et al. (1996) are in accordance to the results of present study, who found the highest $\mathrm{Cd}$ concentration in sheep's milk, lower in goat milk and the lowest in cow milk. Miedico et al. (2015) also found that sheep's milk contain more Cd compared to goat's milk (0.934:0.650 ng/g). Toxic effects of As on the human health are well known (Mandal and Suzuki, 2002). Because As concentrations in ewe milk are very low, we can conclude that this product is not a source of this toxic element.

The correlation between $\mathrm{K}: \mathrm{Na}$ of Karagouniki sheep's milk were strong negative $(r=-0,566, p<0.01)$, but in Serron sheep milk this was only weak $(r=-0,235, p<0,05)$ in investigation Polychroniadou and Vafopoulou (1985). Miedico et al. (2015) determined significant positive correlation in sheep's milk between Fe and Mn (0.65; p<0.01). Pilarzyk et al. (2013) determined in cows' milk of Simmental and Holstein breeds in organic production significant correlation be- tween Ca:P (0.64 and 0.81), Mg:P (0.55 and 0.66). Hermansen et al. (2005) in cows' milk in organic or conventional farming also found positive correlation between concentration of Fe and $\mathrm{Mn}$. Determined concentrations were expected, since the metabolism of the most of essential minerals and potential toxic elements is interwoven. According to determined concentrations of essential and selected toxic elements it can be indicated that milk from Dubrovačka ruda is of high quality and suitable for consumption or cheese production.

\section{Conclusion}

The milk from Dubrovačka ruda is rich in essential minerals and simuntaneously contains lower concentrations of potential toxic, especially $\mathrm{Cr}$, $\mathrm{Cd}, \mathrm{Pb}, \mathrm{As}$ and $\mathrm{Hg}$. The low concentrations of these elements in milk indicate the safety for consumers and preserved environment of DubrovnikNeretva County indicating good quality milk from Dubrovačka ruda, suitable for production of good quality traditional cheeses and other products. The concentration of $\mathrm{Mg}, \mathrm{Na}, \mathrm{Se}, \mathrm{Mn}, \mathrm{Mo}$ and $\mathrm{Cd}$ significantly increased, and $\mathrm{K}$ concentration decreased in milk during the lactation.

\section{Acknowledgement}

The research required for the present study were the part of the project 079-1780469-0225 financed by Ministry of Agriculture, Republic of Croatia.

\section{Utjecaj stadija laktacije na koncentraciju esencijalnih $i$ pojedinih toksičnih elemenata u mlijeku dubrovačke rude- hrvatske ugrožene pasmine}

\section{Sažetak}

Cilj ovog istraživanja bio je utvrditi utjecaj stadija laktacije na koncentraciju esencijalnih i pojedinih toksičnih elemenata $u$ mlijeku ovaca pasmine dubrovačka ruda. Istraživanje je provedeno s 
23 ovce, prosječne dobi od 4 godine, u 3. laktaciji. Uzorci mlijeka uzeti su tijekom rane (60. dan), srednje (90. dan) i kasne (120. dan) laktacije. Ovce su bile odabrane prema jednakim tjelesnim proporcijama, odgovarajućem zdravstvenom stanju, tjelesnoj kondiciji, dobi (4 godine), redoslijedu laktacije (3. laktacije), stadiju laktacije $( \pm 7$ dana) i veličini legla (jedno janje). Ovce su držane na ekstenzivnim mediteranskim pašnjacima, a nakon napasivanja u staji. Hranidba se temeljila na sijenu ad libitum i krmnim smjesama u prosječnoj količini od $0,5 \mathrm{~kg} / \mathrm{dan}$. Uzorci mlijeka su bili prikupljeni tijekom jutarnje mužnje od svake ovce. Razoreni uzorci su analizirani hidridnom tehnikom pomoću induktivno spregnute plazme za utvrđivanje koncentracije $\mathrm{Ca}$, $\mathrm{Mg}, \mathrm{K}, \mathrm{P}, \mathrm{Na}, \mathrm{Cu}, \mathrm{Fe}, \mathrm{Zn}, \mathrm{Mn}, \mathrm{Ni}, \mathrm{Mo}, \mathrm{Co}, \mathrm{Cr}, \mathrm{Cd}$ i $\mathrm{Pb}$. U mlijeku je utvrđen značajan porast koncentracije $\mathrm{Mg}, \mathrm{Na}, \mathrm{Se}, \mathrm{Mn}, \mathrm{Mo}$ i Cd, kao i smanjenje koncentracije $\mathrm{K}$ tijekom laktacije. Iako su koncentracije $\mathrm{Ca}, \mathrm{Cu}, \mathrm{Cr}$ i As u mlijeku tijekom laktacije povećane, razlike između stadija laktacije nisu utvrđene. Koncentracije $\mathrm{P}, \mathrm{Fe}, \mathrm{Ni}, \mathrm{Pb}$ i $\mathrm{Hg}$ u mlijeku dubrovačke rude nisu se razlikovale tijekom laktacije. Niske koncentracije toksičnih elemenata u mlijeku ukazuju na sigurnost konzumacije mlijeka kao i očuvani okoliš Dubrovačko-neretvanske županije.

\section{Ključne riječi: ovce, mlijeko, esencijalni elementi, toksični elementi, stadij laktacije}

\section{References}

1. Al-Wabel, N.A. (2008): Mineral contents of milk of cattle, camels, goats and sheep in the central region of Saudi Arabia, Asian Journal of Biochemistry 3 (6), 373-375.

2. Anastassio, A., Caggiano, R., Macchiato, M., Paolo, C., Ragosta, M., Paino, S., Cortesi, M.L. (2006): Heavy metal contaminations in dairy products from sheep milk collected in two regions of southern Italy, Acta Veterinaria Scandinavica 47, 69-74. doi: 10.1186/1751-0147-47-69

3. Antunović, Z., Steiner, Z., Senčić, Đ., Mandić, M., Klapec, T. (2001): Changes in ewe milk composition depending on lactation stage and feeding season, Czech Journal of Animal Science 46, 75-82.

4. Antunović, Z., Bogut, I., Senčić, Đ., Katić, M., Mijić, P. (2005): Concentrations of selected toxic elements (cadmium, lead, mercury and arsenic) in ewe milk in dependence on lactation stage, Czech Journal of Animal Science 50 (8), 369-375.
5. Antunović, Z., Marić, I., Senčić, Đ., Novoselec, J. (2011a): Exterior characteristic of Dubrovnik sheepCroatian endangered breed, Proceedings of the Third International Conference, June 8-10 2011 Lozenec (Bulgaria) 1, 1-4.

6. Antunović, Z., Marić, I., Steiner, Z., Vegara, M., Novoselac, J. (2011b): Blood metabolic profile of the Dubrovnik sheep - Croatian endangered breed, Macedonian Journal of Animal Science 1 (1), 35-38.

7. Antunović, Z., Novoselec, J., Klir, Ž. (2012): Sheep and goat breeding in the Republic of Croatia - present situation and perspective, Krmiva 54 (3), 99-109.

8. Antunović, Z., Marić, I., Novoselec, J., Klir, Ž. (2015): Influence of lactation stage on the milk quality of Dubrovnik sheep. Proceedings of 50 th Croatian and 10th International Symposium on Agriculture. Opatija (Croatia), 405-409.

9. Bates, C.J, Prentice, A. (1996): Vitamins, minerals and essential trace elements, Drugs and Human Lactation 533-607. doi: 10.1016/B978-044481981-9/50026-6

10. Belete, T., Hussen, A. and Rao, V.M. (2014): Determination of concentrations of selected heavy metals in cow's milk: Borena Zone, Ethiopia, Journal of Health Science 4 (5), 105-112. doi: 10.5923/j.health.20140405.01

11. Bosnak, C.P. and Davidowski, L. (2004): Continuous flow hydride generation using the optima ICP. Field application report. PerkinElmer Life and Analytical Sciences.

12. Caggiano, R., Sabia, S., D’ Emilio, M., Macchiato, M., Anastasio, A., Ragosta, M., Paimo, S. (2005): Metal levels in fooder, milk, dairy products, and tissues sampled in ovine farms of Souther Italy, Environmental research 99, 48-75. doi: 10.1016/j.envres.2004.11.002

13. Cashman, K.D. (2006): Milk minerals (including trace elements) and bone health, International Dairy Journal 16, 1389-1398. doi: 10.1016/j.idairyj.2006.06.017

14. Coni, E., Bocca, A., Coppolelli, P., Caroli, C., Cavallucci, C., Trablaza Marinucci, M. (1996): Minor and trace element content in sheep and goat milk and dairy products, Food Chemistry 57 (2), 253-260. doi: 10.1016/0308-8146(95)00216-2

15. Croatian Agricultural Agency (2015): Godišnje izvješće. Ovčarstvo, kozarstvo i male životinje, Križevci, 121.

16. Gerchev, G., Mihaylova, G. (2012): Milk yield and chemical composition of sheep milk in Srednostaroplaninska and Tetevenska breeds, Biotechnology in Animal Husbandry 28 (2), 241-251. doi: 10.2298/BAH1202241G

17. Ghidini, S., Zanardi, E., Conter, M., Ianieri, A. (2012): Chemical residues in organic meats compared to conventional meats. In: Organic meat production and processing. Eds: Ricke SC, Van Loo EJ, Johnson MG, O’Bryan CA. Wiley, Iowa, USA, Oxford UK, 275-284. 
18. Gonzȧlez-Montaña, J.R., Senís, E., Guttiérrez, A., Prieto, F. (2012): Cadmium and lead in bovine milk in the mining area of the Caudal River (Spain), Environmental Monitoring and Assessment 184 (7), 4029-4034. doi: 10.1007/s10661-011-2241-1.

19. Hermansen, J., Badsberg, J.H., Kristensen, T., Gundersen, V. (2005): Major and trace elements in organically or conventionally produced milk, Journal of Dairy Research 72, 362-368. doi: 10.1017/S0022029905000968

20. Houpert, P., Mehennaoui, S., Federspiel, B., Kolf-Clauw, M., Joseph-Enriquez, B., Milhaud, G. (1997): Transfer of cadmium from feed to ewe food products: variations in transfer induced by lead and zinc, Environmental Sciences 5, 127-138.

21. ISO 11464: 1994 (1994): Soil quality - Pretreatment of samples for physico-chemical analyses. Geneva, Switzerland: International Organisation for Standardization (ISO).

22. ISO 11466: 1995(E) (1995): Soil quality - Extraction of trace elements soluble in aqua regia. Geneva, Switzerland: International Organisation for Standardization (ISO).

23. Ivanova, S., Pacinovski, N., Raicheva, E., Abadjieva, D. (2009): Mineral content of milk from dairy sheep breeds, Macedonian Journal of Animal Sciences 1 (1), 67-71.

24. Ivanova, S. (2011): Dynamical changes in the trace element composition of fresh and lyophilized ewes' milk, Bulgarian Journal of Agricultural Science 17 (1), 25-30.

25. Khan, Z.I., Ashraf, M., Hussain, A., McDowell, L.R., Ashraf, M.Y. (2006): Concentration of minerals in milk of sheep and goats grazing similar pastures in semiarid region of Pakistan, Small Ruminanat Research 65, 274-278. doi: 10.1016/j.smallrumres.2005.07.050

26. Konuspayera, G., Faye, B.S., Loiseau, G., Diacono, E., Akhmetsadykova, S. (2009): Pollution of camel milk by heavy metal sin Kazakhstan, The Open Environment Pollution and Toxicology Journal 1, 112-118. doi: 10.2174/18763979009010100112

27. Mandal, B.K., Suzuki, K.T. (2002): Arsenic round the world: A review, Talanta 58, 201-235. doi: 10.1016/S0039-9140(02)00268-0

28. Marić, I., Antunović, Z., Speranda, M., Marković, B., Novoselec, J., Klir, Ž. (2014): Effect of nutrition and age on metabolic profile of lambs Dubrovnik Ruda. Preceeding of the $49^{\text {th }}$ Croatian \& $9^{\text {th }}$ International Symposium on Agriculture, February $16^{\text {th }}-21^{\text {nd }} 2014$, Dubrovnik, Croatia, 610-614.
29. Mata, L., Perez, M.D., Puyol, P., Calvo, M. (1995): Distribution of added lead and cadmium in human and bovine milk, Journal of Food Protection 58, 305-309.

30. Mehennaoui, S., Houpert, P., Federspiel, B., Joseph-Enriquez, B., Kolf-Clauw, M., Milhaud, G. (1997): Toxicokinetics of lead in the lactating ewe: Variations induced by cadmium and zinc, Environmental Sciences 5, 65-78.

31. Miedico, O., Tarallo, M., Pompa, C., Chiaravalle, E. (2015): Trace elements in sheep and goat milk samples from Apulia and Basilicata regions (Italy). Valuation by multivariate data analysis, Small Ruminant Research 135, 60-65. doi: 10.1016/j.smallrumres.2015.12.019.

32. Mioč, B., Ivanković, A., Pavić, V., Barać, Z., Vnučec, I., Čokljat, Z. (2004): Exterior characteristics and blood protein polymorphisms of Ruda sheep, Stočarstvo 57 (1), 3-11.

33. Mwaura, S.M., Akinsoyinu, A.O. (2010): Calcium and phosphorus in milk of Yankanasa ewes as influenced by stages of lactation, Journal of Applied Biosciences 26, 1623-1630.

34. Polychroniadou, A., Vafopoulou, A. (1985): Variations of major mineral constituents of ewe milk during lactation, Journal of Dairy Science 68, 147-150. doi: 10.3168/jds.S0022-0302(85)80808-0

35. Rodriguez, E.M.R., Uretra, E.D., Romero, C.D. (1999): Concentrations of cadmium and lead in different types of milk, Zeitschrift fuer Lebensmittel Untersuchung und Forschung A - European Food Research and Technology 208, 162-168.

36. Sahan, N., Say, D., Kacar, A. (2005): Changes in chemical and mineral contents of Awassi ewes' milk during lactation, Turkish Journal of Veterinary and Animal Sciences 29, 589-593.

37. SAS 9.3: SAS Institute Inc., Cary, NC, USA.

38. Suttle, N.F. (2010): Mineral nutrition of livestock. 4th ed. CABI International, Wallingford, UK, Cambridge, USA, 587.

39. Vahčić, N., Hruškar, M., Marković, K., Banović, M., Colić Barić, I. (2010): Essential mineral in milk and their daily intake through milk composition, Mljekarstvo 60 (2), 77-85.

40. Zamberlin, Š., Antunac, N., Havranek, J., Samaržija, D. (2012): Mineral elements in milk and dairy products, Mljekarstvo 62 (2), 111-125. 